\title{
SOSIALISASI DAN PENGABDIAN KEPADA MASYARAKAT BERDASARKAN NILAI BERBUDILUHUR DI TENGAH PANDEMI COVID-19
}

\author{
Umaimah Wahid, Wendi Usino, Nawiroh Vera, M. Alfansyah Harahap, \\ Geri Suratno, Imelda Imelda, Anastasya Putri Christanty, Mulyati
}

\author{
Universitas Budi Luhur \\ umaimah.wahid@budiluhur.ac.id
}

\begin{abstract}
The COVID-19 pandemic has changed the world in all sectors, particularly the health, economy, and education sectors. World Health Organization (WHO) announced the coronavirus outbreak (COVID-19) as a global pandemic. Therefore each country began implementing social distancing policies. The President of Indonesia insists on doing all home activities: work at home, study at home, and worship at home. Budi Luhur University carried out the President's appeal by carrying out work and learning activities from home by prioritizing the entire academic community's health and safety. It is also a form of value embodiment of responsibility, cooperation, love, mutual help, being patient, and being grateful for the situation during a pandemic. Services are provided in personal protective equipment (PPE) to hospitals around Jakarta to protect doctors and health workers. The services implemented also consist of socializing to the public about social distancing, washing hands regularly, wearing masks, staying at home campaigns, and providing handwashing places for online taxi bike drivers. The strategic steps exerted in the form of dedication to various communities are based on human values and the embodiment of the mental attitude of the philosophical value "Cerdas Berbudiluhur."
\end{abstract}

Keywords: Socialization, Cultural values, Community Service, COVID-19

\begin{abstract}
Abstrak
Pandemi COVID-19 telah mengubah dunia pada semua sektor, terutama sektor kesehatan, ekonomi dan Pendidikan. WHO mengumumkan wabah virus corona (COVID-19) sebagai Pandemi global, maka setiap negara mulai menerapkan kebijakan social distancing. Presiden Indonesia menghimbau untuk melakukan semua akativitas dari rumah; bekerja di rumah, belajar di rumah, dan beribadah di rumah. Universitas Budi Luhur melaksanakan himbaun Presiden dengan melakukan Aktivitas kerja dan belajar dari rumah dengan mengedepankan kesehatan dan keselamatan seluruh civitas academica, yang sekaligus sebagai bentuk penjawantahan nilai tanggung jawab, kerja sama, cinta kasih, tolong menolong dan sabar mensyukuri situasi ditengah pandemi. Pengandian dalam bentuk bantuan diberikan dalam bentuk alat pelindung diri (ADP) kepada rumah sakit-rumah sakit di sekitar Jakarta untuk melindungi dokter dan tenaga kesehatan, mensosialisasi kepad amasyarakat menegnai social distancing, mencui tangan, mnggunakan masker, kampanye stay at hom, dan menyediakan tempat cuci tangan. bagi para ojek online. Langkah strategis pengabdian kepada masyarakat yang didasarkan nilai-nilai kemanusian dan sekaligus merupakan penjawantahan berbagai bentuk sebagai upaya sungguh-sungguh dari sikap mental nilai filosofis "Cerdas Berbudiluhur'.
\end{abstract}

Kata kunci: Sosialisasi, Nilai-nilai Kebudiluhuran, Pengabdian, COVID-19 


\section{PENDAHULUAN}

Pada tanggal 30 Januari 2020 WHO mengumumkan wabah virus corona popular disebut sebagai COVID19 sebagai Pandemi global, hal ini dikarenakan wabah tersebut telah menjangkiti 210 dari 241 negara di dunia. Data sampai dengan 22 Mei 2020 jumlah total kasus virus corona di dunia adalah sebanyak 5.213.678 kasus. Dari angka tersebut, ada 334.995 kasus kematian yang tercatat dan 2.093.874 pasien telah dinyatakan sembuh. Adapun jumlah kasus aktif hingga kini adalah sebanyak 2,78 juta kasus dengan 2,74 juta kondisi ringan dan 45.602 pasien dalam kondisi serius atau kritis (Bramasta, 2020). Indonesia termasuk salah satu negara yang terjangkiti virus COVID-19. Terus bertambahnya jumlah kasus COVID-19 di Indonesia disinyalir akibat dari kebijakankebijakan pemerintah yang kurang tegas. Pemerintah dinilai terlalu lama mengambilkan sikap sebagai upaya memutuskan penyebaran virus COVID19 yang sudah sangat mengkhawatirkan banyak pihak. Bertebaran asumsi publik bahwa kita sebagai negara tropis yang banyak mengonsumsi empon-empon, banyak berdoa dan biasa makan nasi kucing, akan kebal terhadap COVID19. Ternyata Indonesia tidak kebal dan sampai akhir Februari 2020, COVID-19 sudah muncul di beberapa kota dan terus bertambah jumlahnya (Pambagio, 2020).

Apapun kondisinya, pentingnya kesiapan setiap negara dalam menghadapi epidemi baru. Melalui International Health Regulation (2005), WHO bersama semua negara anggota telah bersepakat menjalankan traktat internasional untuk meningkatkan kapasitas negara menghadapi wabah melalui pendekatan cegah, deteksi dan respons seperti masa pandemi flu
Spanyol pada 1918, serta polio, SARS, MERS-CoV, dan ebola. Akhirnya, setelah 102 tahun, pada 10 Maret 2020, pandemi kembali diumumkan untuk penyakit dengan nama COVID-19 (Saminarsih, 2020). Namun upaya untuk menghadapi dan keluar dari virus ini terus diupayakan, dan beberapa negara telah dianggap berhasil berjuang menaklukkan pandemi COVID-19. Disisi lain, direktur World Health Organization (WHO) Mile Ryan memprediksi COVID-19 kemungkinan tidak akan pernah pergi atau mati total, namun akan terus ada ditengah masyarakat (Kurnia, 2020)..

Pemerintah mengambil berbagai kebijakan dan langkah strategis penanganan COVID-19 dengan mengutamakan kesehatan dan kemanusiaan yang diharapkan segera dapat menuju kehidupan normal. Kebijakan yang tepat akan menentukan kualitas penanganan dan kemampuan Indonesia keluar dari wabah yang telah memporak-porandakan berbagai sektor kehidupan; kesehatan, ekonomi, agama dan juga pendidikan. Kebijakan dan langkah strategis diperlukan dalam upaya penanganan pandemi secara terencana, strategis dan terukur. Merujuk pada (Febriani et al., 2020) bahwa kebijakan yang lambat menjadi salah satu penyebab Indonesia menjadi negara yang penyebaran COVID-19 berlangsung cukup masif. Ditambah dengan berbagai pernyataan resmi dari pemerintah pusat dan kebijakan inkonsistensi yang telah dikeluarkan dalam menangani wabah pandemi COVID-19 yang berdampak pada masyarakat yang memiliki rasa krisis yang rendah, di mana situasinya akan membentuk masyarakat yang cenderung bersikap acuh tak acuh terhadap langkah-langkah strategis yang diterapkan oleh pemerintah. 
Menurut (Lowi, 1964 dalam Febriani et al., 2020), membuat kebijakan memang tidak mudah, ketika kepentingan politik berbagai institusi, aktor, hingga tujuan yang dimotivasi oleh perbedaan masih dipertahankan. Sedangkan Carl D. Friedrick (Islam, 1984), kebijakan merupakan "serangkaian tindakan yang diusulkan seseorang kelompok atau pemerintah yang menunjukkan hambatan-hambatan dan kesempatan-kesempatan terhadap pelaksanaannya dalam rangka mencapai tujuan (Mariyati, 2013). Artinya, membuat kebijakan tidak mudah dan pelaksanaannya tidak selalu mulus, namun kebijakan mengandung kesempatan untuk mengubah keadaan krisis yang sedang dihadapi. Hal tersebut juga terjadi dalam upaya berkompromi dengan COVID-19, dunia pendidikan mengalami berbagai kendala namun sekaligus terdapat tantangan dan kesempatan menghadapi realitas baru. Bagaimanapun kondisi akibat COVID19, sektor pendidikan tetapkan harus berjalan tanpa menimbulkan masalah kesehatan dan kemanusian yang lebih luas.

Masyarakat menghadapi situasi
'shock' karena COVID-19 yang
merupakan virus baru, namun
penyebarannya sangat cepat ke seluruh
dunia. Virus yang belum ada obatnya
ternyata cepat menular dan menjadi
penyebab kematian dalam waktu yang
cepat. Ketidaksipan bukan hanya
dialami oleh masyarakat, pemerintah
pun menghadapi sbeuah situasi yang
dahsyat karen ahal ini bukan saja terkait
keseatan, meliankan merambah ke
berbagai sektor lainnya, baik ekonomi,
pedidikan, sosial budaya dan
keagamaan. Adanya virus telah
mengubah tatanan kehidupan
masyarakat bahkan dunia di hampir
seluruh dunia. Kondisi tersebut
menyebbakan banyak masyarakat

kehilangan pekerjaan, penghaislan yang berkurang, interaksi sosial seacara face to face communication dihindari bahkan sebagian sektor hilang digantikan dengan interaksi online.

Masyarakat harus mengikuti anjuran pemetintah utnuk stay at home, kerja, sekolah dan ibadah di rumah terutama pada bulan-bulan awal penyebaran pandemi COVID-19. Kebijakan pencegahan yang diterapkan oleh pemerintah dalam upaya melindungi masyarakat, telah menyebabkan masyarakat telah berakibat hilangnya pekerjaan sebagian masyarakat sehingga mereka mengalai kekuarangan pangan untuk kebutuhan sehati-hari. Mereka harus mematuhi jaga jarak, cuci tangan dan melkaukan belajar, sekolah dan ibadah di rumah. Artinya jika tidak ada hal yang mendesak diharapkan tinggal di rmah saja.

Berdasarkan fenomena dan kondisi masyarakat yang mengami dampak besar karena pandemi COVID19, maka TIM pengabdian kepada masyarakat Universitas Budi Luhur mengadakan sosialisasi pentinya menjaga jaran, cuci tangan dan beraktivitas di rumah saja. Sosialisasi dilakukan kepada masyarakat di sekitar kampus Universitas Budi Luhur Cileduk. Sosialisasi juga kepada para pengumudi online yang pangkal di depan kampus, sekaligus menyediakan wadah cuci tangan. Dismaping sosialisasi, TIM yang didukung oleh Yayasan Budi Luhur Cakti dan Universitas Budi Luhur membagikan makanan pokok kepada masyarakat dan ojek online. Pada saat yang sama juga menyerahkan bantuan Alat Pleindung Diri (APD) kepada beberapa rumah sakit di Jakarta. 


\section{METODE}

Pelaksaaan kegiatan pengandian masyarakat oleh TIM Dosen dan didukung Corporate Social Responsibiity (CSR) Universitas Budi Luhur sebagai upaa mendukung kebijakan langkah strategis pemerintah dalam penanganan pandemi COVID-19, dan implementasi nilai-nilai kebudiluhuran yang merupakan folisofi Universitas Budi Luhur. Kegiatan pengabdian dilakukan pada bulan Maret, April dan Mei 2020. Beberapa bentuk kegiatan dan lokasi dipilih sesuai dengan kebutuhan mendesak saat awal pandemi COVID-19 merebak. Dalam rangka mencapai tujuan dan target yan ditetapkan, maka kegiatan pengabdian kepada masyarakat di masa pandemi COVID-19 ini meliputi kegiatan sosialisasi mengenai pandemi kepada masyarakat di sekitar lingkungan Universitas Budi Luhur yaitu Pesanggarahan Utara Jakarta Selatan, para pengemudi ojol yang pangkalannya di depan kampus UBL, para penguna jalan raya di depan UBL. Sosialisasi diberikan mengenai pengetahuan dan pemahaman bahaya pandemi COVID-19, cara menghindari penularan, anjuran mematuhi ketentuan pemerintah mengenai jaga jarak (social distancing), menggunakan masker, cuci tangan dan memilih untuk lebih banyak di rumah saja jika tidak ada keperluan mendesak, dan jikalau pun harus keluar rumah dengan mematuhi protocol kesehatan agar tidaktertular dan menularkan kepada orang lain. Disamping memberikan sosilisasi, Tim juga memberikan bantuan yang snagat dibutuhkan oleh masyarakat kena imbas COVID-19 yaitu bantuan kebutuhan pokok.

COVID-19 mau tidak mau menempatkan tenaga kesehatan baik dokter dan tenaga media pada garda terdepan dalam pelayanan melawan COVID-19. Mereka menjadi pihak yang paling rentan tertular dari pasien-pasien yang berobat. Salah satu yang dapat menghindari penularan adalah penggunaan Alat Pelindung Diri (ADP) memberikan dukungan kemanusiaan berupa bantuan Alat Pelindung Diri (PD) kepada beberapa rumah sakit diantaranya Rumah Sakit Pasar Minggu, Rumah Sakit Daerah Tarakan, Rumah Sakit Persahabatan, Rumah Sakit RSPI Sulianti Saroso sebagai RS Rujukan Utama Pasien COVID-19.

Proses pelaksanaan kegiatan dimulai dari perencanaan dan merancang kegiatan yang dibutuhkan oleh masyarakat di masa pandemi-19. Perencanaan melibatkan beberapa orang TIM utama dan tim pendukung karena beberapa kali kegiatan yang dilakukan. Perencanaan tersebut juga melibatkan Ketua Yayasan Budi Luhur Cakti yang sangat konsen terhadap upaya- dan langkah-langkah bernilai kemanusiaan dalam upaya implementasi nilai-nilai kebudiluhuran. Yayasan dan Universitas Budi Luhur bukan hanya melakukan pengembangan akal pemikiran anak didik atau mahasiswa, melainkan juga selalu menyeimbangkan dengan kekuatan nilai-nilai kebudiluhuran yang melandasi setiap perbuatan warga Budiluhur. Oleh karenanya merupakan suatu kemestian bagi warga budiluhur untuk melakukan tindakan nyata kepada masyarakat yang membutuhkan di masa pandemi COVID-19 ini. Langkah-langkah yang dilakukan dalam kegiatan pengembangan masyarakat tersebut sebagai berikut:

1. Penentuan target, sasaran dan tujuan kegiatan

2. Perumusan TIM Pelaksana dan kapasitasnya

3. Perumusan masalah dan solusi Sasaran 
Umaimah Wahid, dkk. Sosialisasi Dan Pengabdian Kepada Masyarakat Berdasarkan ...

4. Penyusunan Metode Kagiatan dannMeteri Kegiatan PPM

5. Penentuan kebutuhan/dukungan kepada Masyarakat

6. Pelaksanaan Kegiatan

7. Evaluasi Kegiatan

\section{HASIL DAN PEMBAHASAN}

Kegiatan pengabdian kepada masyarakat, Universitas Budi Luhur melakukan beberapa kegiatan, yaitu:

1. Sosialisasi mengenai pengetahuan penyebaran virus COVID-19 dan anjuran untuk menjaga jarak, cuci tangan, menggunakan masker dan melakukan belajar, kerja dan ibadah di rumah saja.

2. Berbagi sembako demi meringankan warga terdampak pandemi COVID19 dan para jurnalis.

3. Melakukan penyemprotan disinfektan di lingkungan kampus dan masyarakat sekitar kampus.

4. Penyerahan sumbangan APD kepada RSUD Pasar Minggu, RSUD Tarakan, RSUD Tangerang, RSUP Persahabatan, RSPI Sulianti Saroso, RS Wisma Atlet Kemayoran dll.

5. Penyerahan sumbangan APD kepada penggali kubur di TPU Pondok Rangon.

6. Penyerahan sumbangan nasi box kepada pengendara OJOL, pemulung dan warga sekitar kampus.

7. Memberikan bantuan sembako untuk kusir dokar, dan pakan kuda untuk kuda penarik dokar di kawasan Petukangan Utara, lokasi Kampus UBL.

8. Membangun sarana mencuci tangan yang dapat digunakan oleh masyarakat di sekitar kampus.

Kegiatan pengabdian kepada masyarakat sebgaaimana terlihat dalam gambar 1.

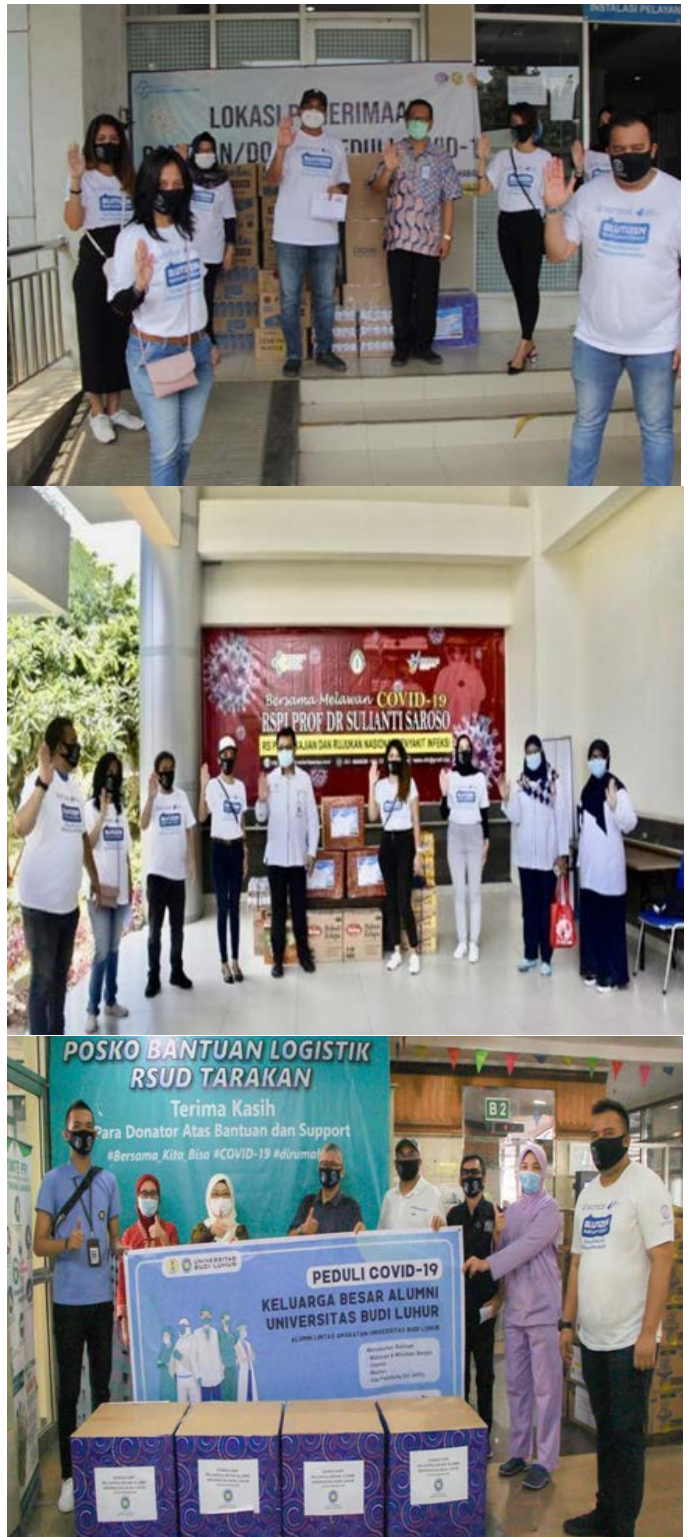

Gambar 1. Universitas Labuhan Batu donasikan APD dan masker kepada tenaga kesehatan

Kegiatan Sosialisasi dan bantuan kebutuhan pokok, Alat Pelindung Diri (ADP), membangun dan wadah cuci tangan merupakan wujud keseimbangan antara ketiga dimensi raga, jiwa, dan spiritual adalah sebuah keharusan untuk mencapai manusia Indonesia seutuhnya. Dalam konsep pemikiran Jawa, manusia terdiri atas tiga lapis, yaitu raga, sukma, dan sukma sejati (Wahid, 2018). Kegiatan PPM yang dilaksanakan dengan gembira oleh 
TIM Universitas budi Luhur merupakan penjewantahan dari nilai-nilai kebudiluhuran. Kegiatan PPM dalam situasi dan kondisi masyarakat sedang menghadapi krisis dampak dari COVID-19, sangat dibutuhkan oleh masyarakat dan juga tenagan kesehatan atau rumah sakit dalam penanganan COVID-19. Sekaligus jugabentuk dukungan kampus UBL atas kebijakan dan lengkah strategi pemerintah dalam upaya penanganan COVID-19.

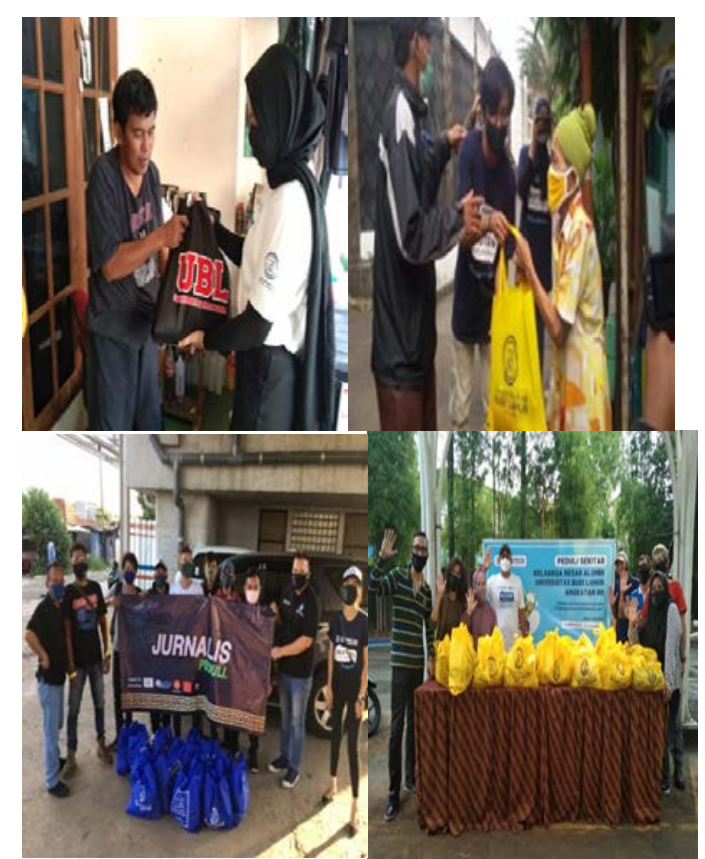

Gambar 2. Sosialisasi Menggikui Anjuran Cuci tangan, menggunakan masker dll, dan Pembagian sembako, dokumen Universitas Budi Luhur

Masyarakat yang menjadi target sosialisasi menerima dengan baik kegiatan tersebut, baik sosialisasi, maupun bantuan pangan, dan APD. Kegiatan merupakan wujud dari nilai baik yang harus dibagi kepada masyarakat terlebih ditengah musibah nasional pandemi COVID-19 yang dialami bangs aindoensia bahkan dunia. Proses pemikiran dan gerak langkah Universitas Budi luhur pada masa COVID-19 dilakukan atas pertimbangan nilai etika yang dikenal dengan nilai-nilai "Cerdas Berbudiluhur”. Kegiatan tersebut sekaligus bentuk perbuatan baik sebagai manusia yang wajib membantu sesame manusia lainnya. Justru semua aktivitas tersbeut menambah nilai kemanusian. Merujuk pada (Mintz, 2018), nilai sangat penting untuk etika dan, etika berkaitan dengan pilihan tindakan manusia. Nilai memberikan keberanian dan kekuatan untuk bertindak dalam kehidupan sehari-hari. Keberanian adalah nilai moral ketika berurusan dengan perilaku benar dan salah. Hal tersebut sangat penting dan mendasar bagi semua tindakan manusia sebagai bentuk tanggung jawab sesama manusia dan pencipta. Merujuk pada (Djaetun, 2017) bahwa "orang baik selalu dibedakan Tuhan; dimanapun, kapanpun dan dalam situasi apapun”.

Tindakan manusia tidak bermakna tanpa didasari oleh etika moral, sekaligus menciptakan keseimbangan memelihara keharmonisan. Merujuk pada Filosofi Yayasan Pendidikan Budi Luhur Cakti yang disampaikan oleh (Djaetun, 2017), "Cerdas berbudi luhur adalah dua hal yang tidak terpisahkan, kecerdasan tanpa diimbangi budi luhur akan cenderung untuk membodohi dan mencelakakan orang lain, sebaliknya budi luhur tanpa diimbangi kecerdasan akan menjadi sasaran kejahatan dan penindasan orang lain”. Filosofi ini bermakna bahwa dalam kehidupan memerlukan keseimbangan antara cerdas dan baik. Kecerdasan dimiliki manusia karena proses berpikir, sedangkan kebaikan diperoleh manusia dari rasa dan hati nurani. Berdasarkan nilai filosofi itulah, Universitas Budi Luhur mempunyai tanggung jawab secara moral untuk mengedepankan keselamatan, kesehatan dan kesinambungan proses belajar mengajar 
dalam kondisi pandemi COVID-19. Semua civitas akademika menjadi tanggung jawab UBL untuk menjamin warga UBL sehat, namun tetap dapat belajar dan bekerja dengan melakukannya di rumah.

Kegiatan PPM terlaksana karena adanya kerja sama diantara berbagai pihak, baik TIM pelaksana, Yayasan, Universitas dan mahasiswa. Merujuk pada filosofi Cerdas Berbudiluhur (Djaetun, 2017), kerja sama adalah melakukan kegiatan dengan orang/ pihak lain, dengan cara menyatukan mensinergikan potensi/ kekuatan untuk mencapai suatu tujuan yang diinginkan. Seseorang atau kelompok yang melakukan kerja sama, maka akan melakukan kegiatan didasarkan pertimbangan moral, "tidak konflik, saling membantu untuk memperkuat dan sekaligus memberdayakan.” Rasa kebersamaam dalam situasi krisis seperti COVID-19 sangat dibutuhkan oleh masyarakat agar dapat 'merasa bersama-sama' dalam situasi yang kurang menentu dan cenderung mengkhawatirkan bagi banyak pihak.

Dalam situasi krisis, kerja sama diantara anggota kelompok dan organisasi sangat diperlukan, bahkan menjadi sebuah kemestian. Kerja sama merupakan refleksi dari tanggung jawab diharapkan mampu melahirkan solidaritas antar sesama anak bangsa sehingga mempunyai 'energi dan kekuatan yang sama dalam menghadapi COVID-19. Tidak dapat dipungkiri, Indonesia dan bangsa-bangsa di dunia membutuhkan solidaritas dalam menghadapi COVID-19. Kebersamaan akan muncul perilaku-perilaku dan aktivitas yang menggerakkan 'spirit' masyarakat sehingga pandemi COVID19 dipikul bersama-sama agar lebih meringankan bagi warga UBL. Kerja sama juga mampu membangun rasa solidaritas antara sesama masyarakat yang sedang mengalami berbagai krisis di tengah COVID-19.

Emile Durkheim (Ritzer \& Goodman, 2010), melihat solidaritas sosial sebagai suatu gejala moral. Indonesia dapat membangun solidaritas sebagai bangsa yang majemuk berlandaskan kekuatan sosial budaya beragam yang mengikat dan menjadi alasan menggerakkan solidaritas dalam menghadapi normal baru (new normal) di masa COVID-19. Merujuk pada Pandangan (ESCAP, 2020), pemerintah harus mengambil keputusan sulit dalam menanggapi COVID-19 dengan menggunakan kekuatan negara, melestarikan ruang sipil yang demokratis, membangun kepercayaan masyarakat pada lembaga, dan sekaligus membendung meningkatnya diskriminasi, rasisme dan stigmatisasi yang menguat di masa COVID-19. Hal tersebut tumbuh karena kembali menguat ego sektoral yang dapat merusak solidaritas Indonesia sebagai bangsa dan global.

Kampus Universitas Budi Luhur menyadari dampak sosial budaya dan ekonomi dikarenakan COVID-19. Banyak masyarakat yang kehilangan pekerjaan sehingga mempengaruhi penghasilan dan kualitas hidup. Merujuk pada publikasi (Asean Policy Brief, 2020), sejak Organisasi Kesehatan Dunia (WHO) akhirnya mendeklarasikan wabah COVID-19 sebagai pandemi global pada 11 Maret 2020, kehidupan menjadi kacau dan aktivitas ekonomi terganggu di seluruh dunia dan berdampak negatif pada ekonomi ASEAN dan dunia pada tahun 2020 (Asean Policy Brief, 2020) dalam konteks ini, tidak hanya hanya berpikir kepentingan kampus, melainkan mengambil sikap atas dasar nilai kebudiluhran yaitu 'Cinta Kasih", menumbuhkan rasa empati dengan apa 
yang dialami oleh anggota keluarga UBL.

Disamping memberikan keringanan SPP kepada kegiatan kemanusiaan lainnya sebagai wujud nilai kebudiluhuran cinta kasih (welas asih) dan tolong menolong. Merujuk pada (Djaetun, 2017) cinta kasih adalah Peduli terhadap sesama dan lingkungan, baik manusia, flora, fauna dan seluruh isi alam ciptaan Tuhan. Artinya setiap tindakan berusaha untuk mampu memahami perasaan harapan dan keinginan orang/pihak lain atau dengan kata lain berusaha untuk selalu mampu menempatkan diri pada posisi orang/pihak lain sehingga selalu menjaga keharmonisan dan tidak menimbulkan konflik atau tidak merusak.

Bentuk aktivitas welas asih sekaligus merupakan refleksi mental dari sabar mensyukuri kepada Tuhan walau dalam kondisi sesulit apapun, seperti ditengah pandemi COVID-19 ini. Bebgai bentuk kegiatan sebagaiman atelah disebutkan sebelumnya dilakukan untuk mendukung kebiajkan pemerintah, membantu masyarakat dan sekaligus implementasi dari nilai-nilai kebudiluhuran. Kegiatan PPM, dapat disimpulkan bahwa masyarakat memahami bahwa COVID-19 merupakan virus yang berbahaya dan mereka akan mematuhi anjuran pemerintah, sebagaimana materi sosialisasi. Harapannya, masyarakat mematuhi sosialisasi yang disampaikan dakan kegiatan PPM, bukan sekedar hanya karena takut, melainkan lebih karena tanggung jawab manusia untuk menjaga sesama dan berbuat baik.

\section{SIMPULAN}

Kegiatan sosialisasi dan pengabdian kepada masyarakat selama masa COVID-19 dilaksanakan oleh
TIM dosen Universitas Budi Luhur upaya sungguh-sungguh dari sikap mental nilai filosofis "Cerdas Berbudiluhur'. Kegiatan sosialisasi memperoleh dukungan sepenuhnya oleh Yayasan Pendidikan Budi Luhur Cakti melakukan kegiatan-kegiatan kemanusian seperti Universitas Budi Luhur Berbagi Sembako, menggalang donasi dukungan pembelian Alat Pelindung Diri (APD), penyerahan sumbangan APD kepada rumah sakitrumah sakit, RS Wisma Atlet Kemayoran dll, serta penggali kubur di TPU Pondok Rangon, sumbangan nasi box kepada pengendara OJO, sembako bagi mahasiswa perantauan yang tidak bisa pulang kampung, kusir dokar, dan pakan kuda untuk kuda penarik dokar di kawasan Petukangan Utara, lokasi Kampus UBL, membangun sarana mencuci tangan yang dapat digunakan oleh masyarakat di sekitar kampus dan melaksanakan berbagai bentuk kegiatan seminar dan diskusi (Webinar) terkait COVID-19.

Kegiatan pengabdian kepada masyarakat ini sekaligus penjawantahan sikap mental cerdas berbudiluhur dalam kehidupan berbags adan bernegara. Manusia tidak hanya memikirkan dan bertindak atas diri dan untuk dirinya sendiri, melainkan kita semua warga baik warga UBL, masyarakat berbagai komponen bangsa merupakan energi bagi Indonesia untuk menjadi bagian dari penanganan COVID-19 yang dilaksanakan oleh Pemerintah. Kita mampu menjadi bagian aktif, inovatif dan kreatif karena upaya berkompromi dengan COVID-19 membutuhkan energi yang luar biasa, dan sama sekali tidak mungkin dikerjakan oleh salah satu pihak saja, termasuk hanya oleh pemerintah. Kerja sama dan tolong menolong antara semua pihak atau semua warga UBL, atau antara sesama anak bangsa sangat adalah sebuah 
Umaimah Wahid, dkk. Sosialisasi Dan Pengabdian Kepada Masyarakat Berdasarkan ...

kemestian. Indonesia memanggil kita semua, baik pihak kampus dan masyarakat pada umumnya untuk bergerak bersama dengan penuh tanggung jawab, saling membantu membagi kasih untuk Indonesia menuju new normal.

\section{UCAPAN TERIMA KASIH}

Kegiatan PPM ini dapat terselenggara dengan baik karena TIM yang solid dan dukungan beberapa pihak. Oleh karena itu sangat pantas penghargaan dan terima kasih yang sebesar-besar TIM Pelaksana PPM sampaikan kepada Ketua Yayasan Budi Luhur Cakti dan Universitas Budi Luhur, Kasih Hanggoro, M.BA., Rektor Universitas Budi Luhur, RT dan Masyarakat Petukangan Utara, Direktur dan dokter Rumah Sakit RSUD RSUD Pasar Minggu, RSUD Tarakan, RSUD Tangerang, RSUP Persahabatan, RSPI Sulianti Saroso, RS Wisma Atlet Kemayoran

\section{DAFTAR PUSTAKA}

Asean Policy Brief. (2020). Economic Impact of COVID-19 Outbreak on ASEAN. Asean.Org. https://asean.org/storage/2020/ 04/ASEAN-Policy-Brief-April2020_FINAL.pdf.

Ayunda, K. P. (2020). Dukung Tenaga Medis, UBL Donasi APD dan Logistik ke RS Persahabatan. Kompas.Com.

https://edukasi.kompas.com/rea d/2020/04/24/190000671/duku ng-tenaga-medis-ubl-donasi

Bramasta, D. B. (2020). Update Covid-19 di Dunia 9 Juni_ 7,1 Juta Orang Terinfeksi _ Desakan WHO untuk Lanjutkan Perjuangan. Kompas.Com. https://www.kompas.com/tren/ $\mathrm{read} / 2020 / 06 / 09 / 080200565 / \mathrm{up}$ date-covid-19-di-dunia-9-juni-7-1-juta-orang-terinfeksidesakan-who

Djaetun, H. S. (2017). Hakikat Budi Luhur Mengapa kita harus cerdas berbudi luhur? Bagaimana jika tidak?

ESCAP. (2020). The Impact and Policy Responses for COVID19 in Asia and the Pacific.

Febriani, D., Valervan, B., \& Vanissa, N. (2020). Evaluation of Governmen Policy Readiness in The Management of The Covid-19 Pandamy Viewed From The Implemation of Dynamic.

Kurnia, T. (2020). WHO_ Virus Corona COVID-19 Mungkin Akan Terus Ada - Global Liputan6. Liputan6.Com. https://www.liputan6.com/glob $\mathrm{al} / \mathrm{read} / 4253658 /$ who-viruscorona-covid-19-mungkinakan-terus-ada

Mariyati, T. (2013). Strategi Implementasi Kebijakan Publik dalam Mendorong Percepatan Pengembangan Pengguna Internet Public Policy Implementation Strategy in. 147-158.

Mintz, S. (2018). What Are Values? Website Ethic Sage.

Pambagio, A. (2020). Review Kebijakan Penanganan COVID-19 - kumparan. Kumparan.Com;

Kumparan.com.

https://kumparan.com/aguspambagio/review-kebijakanpenanganan-covid-191t40cGQhwwJ

Ritzer, G., \& Goodman, D. J. (2010). Teori Sosiologi Klasik dan Moden. Kreasi Wacana. 
Saminarsih, D. S. (2020). menujustrategi-nasional-penanganancovid-19 (2). Tempo.Com. https://kolom.tempo.co/read/13 28253/menuju-strateginasional-penanganan-covid19/full\&view=ok.
Wahid, U. (2018). Politik (Sejatinya) Berbudi Luhur. SuaraMerdeka.Com. https://www.suaramerdeka.co m/smcetak/baca/120368/politik -sejatinya-berbudi-luhur/ 